University of Nebraska - Lincoln

DigitalCommons@University of Nebraska - Lincoln

Faculty Papers and Publications in Animal

Science

Animal Science Department

1999

\title{
Effects of Imposed Feed Intake Variation on Acidosis and Performance of Finishing Steers
}

\author{
R. J. Cooper \\ University of Nebraska-Lincoln \\ Terry J. Klopfenstein \\ University of Nebraska-Lincoln, tklopfenstein1@unl.edu \\ Rick Stock \\ University of Nebraska-Lincoln, rstock3@Unl.edu \\ C. T. Milton \\ University of Nebraska-Lincoln \\ D. W. Herold \\ University of Nebraska-Lincoln \\ See next page for additional authors
}

Follow this and additional works at: https://digitalcommons.unl.edu/animalscifacpub

Part of the Animal Sciences Commons

Cooper, R. J.; Klopfenstein, Terry J.; Stock, Rick; Milton, C. T.; Herold, D. W.; and Parrott, J. C., "Effects of Imposed Feed Intake Variation on Acidosis and Performance of Finishing Steers" (1999). Faculty Papers and Publications in Animal Science. 531.

https://digitalcommons.unl.edu/animalscifacpub/531

This Article is brought to you for free and open access by the Animal Science Department at DigitalCommons@University of Nebraska - Lincoln. It has been accepted for inclusion in Faculty Papers and Publications in Animal Science by an authorized administrator of DigitalCommons@University of Nebraska - Lincoln. 


\section{Authors}

R. J. Cooper, Terry J. Klopfenstein, Rick Stock, C. T. Milton, D. W. Herold, and J. C. Parrott 


\title{
Effects of Imposed Feed Intake Variation on Acidosis and Performance of Finishing Steers ${ }^{1}$
}

\author{
R. J. Cooper, T. J. Klopfenstein'2, R. A. Stock ${ }^{3}$, C. T. Milton, \\ D. W. Herold, and J. C. Parrott ${ }^{4}$
}

University of Nebraska, Lincoln 68583-0908 and Elanco Animal Health, Indianapolis, IN 46285

\begin{abstract}
Four metabolism and two finishing trials were conducted to determine the effects of imposed feed intake variation on acidosis and performance of finishing steers. In Metabolism Trial 1, four ruminally fistulated steers were limit-fed and subjected to either a constant amount of feed per day (C) or low intake variation of $.7 \mathrm{~kg} / \mathrm{d}(\mathrm{LV})$. No treatment differences were found for intake or measures of acidosis. Metabolism Trial 2 was conducted similarly to Metabolism Trial 1 with treatments of $C$ and high intake variation of $1.4 \mathrm{~kg} / \mathrm{d}(\mathrm{HV})$. Treatment $\mathrm{HV}$ increased $(\mathrm{P}<.05)$ acidosis, as indicated by the area of ruminal $\mathrm{pH}$ below 5.6. In Metabolism Trial 3, four steers were fed at ad libitum levels of intake and subjected to three levels of intake variation: ad libitum intake with no imposed intake variation $(A L)$, LV of .7 kg/d, and HV of $1.4 \mathrm{~kg} / \mathrm{d}$. No treatment differences were found. In Metabolism Trial 4, six
\end{abstract}

ruminally fistulated steers were fed at ad libitum levels and subjected to three levels of intake variation: $\mathrm{AL}, \mathrm{LV}$ of $.9 \mathrm{~kg} / \mathrm{d}$, and $\mathrm{HV}$ of $1.8 \mathrm{~kg} / \mathrm{d}$. Average ruminal $\mathrm{pH}$ increased $(\mathrm{P}<.05)$ and area of ruminal $\mathrm{pH}$ below 5.6 decreased $(\mathrm{P}<.05)$ as level of intake variation was increased. In Finishing Trial 1, 75 steers were assigned to eight pens and two treatments: $\mathrm{AL}$ or $\mathrm{HV}$ of $1.8 \mathrm{~kg} / \mathrm{d}$. Dry matter intake increased $(P<.05)$ from $A L$ to HV. Daily gain and gain/feed were not affected by treatment. In Finishing Trial 2, 94 steers were assigned to 12 pens and two treatments: $\mathrm{AL}$ or $\mathrm{HV}$ of $1.8 \mathrm{~kg} / \mathrm{d}$. No treatment differences were noted in DMI, daily gain, or gain/ feed. Therefore, results of these trials indicate that intake variation of up to $1.8 \mathrm{~kg} / \mathrm{d}$ does not increase acidosis or decrease performance of finishing steers fed at ad libitum levels of intake.

Key Words: Cattle, Feed Intake, Acidosis

@1999 American Society of Animal Science All rights reserved.

J. Anim. Sci. 1999. 77:1093-1099

\section{Introduction}

F eed intake variation by cattle fed high-concentrate diets is presumed by most nutritionists and feedlot managers to either predispose to or cause digestive disturbances such as acidosis. Despite this commonly held belief, relatively few data are available to support negative effects of feed intake variation on acidosis and cattle performance. Galyean et al. (1992) found that daily intake variation of $10 \%$ decreased gain and efficiency of steers compared with a constant amount of feed given per day in a limit-feeding management system. However, they also noted that treatment

\footnotetext{
${ }^{1}$ Published with the approval of the director as paper no. 12193 , journal ser., Nebraska Agric. Res. Div.

${ }^{2}$ To whom correspondence should be addressed.

${ }^{3}$ Present address: Cargill, Inc., Blair, NE.

${ }^{4}$ Address: Elanco Animal Health, P.O. Box 416, Council Bluffs, IA 51502-0416.

Received April 23, 1998.

Accepted November 16, 1998.
}

differences narrowed as steers increased in body weight. Feed intake also increased as body weight increased, and presumably approached ad libitum consumption. Therefore, these data might not be applicable to cattle fed for ad libitum intake.

Stock et al. (1995) summarized several individual feeding trials and reported that intake variance was correlated negatively $(r=-.28)$ with gain/feed. Therefore, intake variation had some negative relationship with performance. However, this does not necessarily suggest that intake variation decreased performance directly, but that intake variation is a sign of subacute acidosis, which decreased performance.

The primary symptom of subacute acidosis is reduced and erratic feed intake. However, the cause and effect nature of intake variation and subacute acidosis is unclear. It is not certain whether feed intake variation causes subacute acidosis, or subacute acidosis causes feed intake variation. The objectives of these trials were to evaluate the effect of imposed feed intake variation on acidosis and performance of finishing steers. 


\section{Materials and Methods}

\section{Metabolism Trials}

Four metabolism trials were conducted to determine the effects of imposed feed intake variation on acidosis in finishing steers. In Metabolism Trials 1 and 2, four ruminally fistulated steers were used in switchback designs with three 6-d periods. Steers were fed $80 \%$ of their previously determined ad libitum intake and assigned to either constant or variable intake pattern. In Metabolism Trial 1, treatments consisted of a constant amount of feed given per day (C) and a low daily feed intake variation of .7 kg/d ( LV). I ntake variation was applied by first reducing the amount of feed offered from a steer's C level of intake by $.35 \mathrm{~kg}$ on $\mathrm{d} 1$, then increasing by $.7 \mathrm{~kg}$ on $\mathrm{d}$ 2 , decreasing by $.7 \mathrm{~kg}$ on $\mathrm{d} 3$, and so forth through $\mathrm{d} 6$. In Metabolism Trial 2, treatments consisted of $\mathrm{C}$ and a high daily feed intake variation of $1.4 \mathrm{~kg} / \mathrm{d}(\mathbf{H V})$. Intake variation was applied in a similar manner as Metabolism Trial 1, with twice the magnitude of variation.

In Metabolism Trial 3, the same four ruminally fistulated steers from Metabolism Trials 1 and 2 were fed at ad libitum levels and subjected to three levels of feed intake variation: ad libitum intake with no imposed feed intake variation ( $\mathbf{A L}$ ), $L V$ of $.7 \mathrm{~kg} / \mathrm{d}$, and HV of $1.4 \mathrm{~kg} / \mathrm{d}$. Intake variation was applied in a similar manner as in Metabolism Trials 1 and 2, with the exception that the amount of feed offered was increased and decreased based on a steer's average intake during the $A L$ treatment. Treatments $A L, L V$, and HV were applied to all steers in the 6-d Periods of 1,2 , and 3 , respectively. It is important to note that treatment was confounded with period in this trial. However, because this trial was conducted within a 21-d period in an environmentally-controlled metabolism room, period should have little effect on the results.

In Metabolism Trials 1, 2, and 3, steers were fed a $90 \%$ concentrate diet once daily at 0800 that contained (DM basis) $78.5 \%$ dry-rolled corn, $10 \%$ alfalfa, $7.8 \%$ molasses-urea liquid supplement, and $3.7 \%$ dry supplement. Diets were formulated to contain a minimum of $12.5 \% \mathrm{CP}, .7 \%$ calcium, .3\% phosphorus, and $.6 \%$ potassium, with $27.5 \mathrm{mg} / \mathrm{kg}$ monensin (Elanco Animal Health, Indianapolis, IN) and $11.0 \mathrm{mg} / \mathrm{kg}$ tylosin (Elanco Animal Health).

In Metabolism Trial 4, six ruminally fistulated steers were utilized in a split-plot, crossover design with a $2 \times 3$ factorial arrangement of treatments. Treatments consisted of three levels of imposed intake variation: $A L, L V$ of $.9 \mathrm{~kg} / \mathrm{d}$, and $\mathrm{HV}$ of $1.8 \mathrm{~kg} / \mathrm{d}$. Inclusion of monensin at either 0 or $27.5 \mathrm{mg} / \mathrm{kg}$ was factored across level of intake variation. No monensin $\times$ intake variation interaction was observed $(P>.10)$; therefore, only means for level of intake variation are presented. Intake variation was applied in a similar manner as Metabolism Trial 3. Treatments $A L, L V$, and HV were applied to all steers in Periods 1, 2, and 3 , respectively. The monensin treatment, which was allotted randomly to three steers at the beginning of the trial, was then switched in the crossover. The three steers that were assigned to $27.5 \mathrm{mg} / \mathrm{kg}$ of monensin during Periods 1,2 , and 3 were reassigned to the control diet, and the three steers that were assigned to the control diet during Periods 1, 2, and 3 were reassigned to the $27.5 \mathrm{mg} / \mathrm{kg}$ monensin diet. Following a 15-d adaptation period, treatments $A L$, LV, and HV were again applied to all steers in Periods 4,5 , and 6, respectively. Steers were fed a $92.5 \%$ concentrate diet once daily at 0800 that contained (DM basis) $81.9 \%$ dry-rolled corn, 7.5\% alfalfa, $6.4 \%$ molasses-urea liquid supplement, and $4.2 \%$ dry supplement. Diets were formulated to contain a minimum of $12.5 \% \mathrm{CP}, .7 \%$ calcium, . $3 \%$ phosphorus, and $.6 \%$ potassium, with $27.5 \mathrm{mg} / \mathrm{kg}$ monensin (Elanco Animal Health) and $11.0 \mathrm{mg} / \mathrm{kg}$ tylosin (Elanco Animal Health) depending on dietary treatment.

In metabolism trials, steers were tethered in individual metabolism stalls. Feed intakes were monitored continuously with individual feed bunks that were suspended from load cells (Omega, Stamford, $\mathrm{CT}$ ). Ruminal $\mathrm{pH}$ was monitored continuously with submersible pH electrodes (Sensorex, Stanton CA; J enco, San Diego, CA) suspended through the plug of the ruminal cannula of each steer. Each electrode was encased in a weighted four-wire metal shroud to keep the electrode in a stationary position approximately 15 $\mathrm{cm}$ above the ventral floor of the rumen, while allowing ruminal contents to flow freely. Load cells and $\mathrm{pH}$ electrodes were linked directly to a computer, allowing data acquisition software (Labtech, Wilmington, $\mathrm{MA}$ ) to record both a feed weight and ruminal $\mathrm{pH}$ every minute for each steer during the 6-d collection periods. Surgical and postsurgical care procedures followed those outlined by Stock et al. (1991), and all procedures had been reviewed and accepted by the University of Nebraska Institutional Animal Care Program.

Analysis of acidosis in metabolism trials included $\mathrm{DMI}$, rate of intake, average ruminal $\mathrm{pH}$, and area of ruminal $\mathrm{pH}$ below 5.6. Rate of intake was calculated as the slope through the natural log transformation of the feed weights for a steer for each day. When viewing the intake patterns in graphical form, it seemed that the rates were not linear in nature, but were curvilinear. When linear and quadratic functions were applied to these patterns, quadratic functions had a better fit as indicated by a higher $r^{2}$ compared with linear functions (data not shown). Therefore, rate of intake was considered a first-order function and calculated with the units of percentage per hour. Average ruminal $\mathrm{pH}$ was calculated as the average of the 1,440 measurements recorded during each 24-h collection day. Area of ruminal pH curve below 5.6 was calculated by subtracting each ruminal $\mathrm{pH}$ 
value obtained during a day from 5.6. All positive values for the day were then summed. Area of ruminal $\mathrm{pH}$ below 5.6 has the units of magnitude of $\mathrm{pH}$ below 5.6 by minute. The $\mathrm{pH}$ of 5.6 is not critical in the calculation, but seems to be a good baseline because it is generally the $\mathrm{pH}$ used when defining subacute acidosis. Fulton et al. (1979) found that steers had reduced intake until ruminal $\mathrm{pH}$ returned above 5.6. Therefore, area of ruminal $\mathrm{pH}$ below 5.6, which measures the time and extent below 5.6, should be a good measure of subacute acidosis. Bauer et al. (1995) used a similar calculation to measure the area of ruminal pH below 6.0.

Data from Metabolism Trials 1 and 2 were analyzed as switchback designs using the mixed procedure of SAS (1990). Steer was the experimental unit. The model included treatment, with steer and period as random effects. Least squares means were separated using least significant difference method when a significant $(\mathrm{P}<.10)$ F-test was detected.

Data from Metabolism Trial 3 were analyzed as a completely randomized design using the mixed procedure of SAS (1990). Steer was the experimental unit. The model included treatment with steer as a random effect. Period was assumed to have no effect because period and treatment were confounded. Least squares means were separated using least significant difference method when a significant $(P<.10) F$-test was detected.

Data from Metabolism Trial 4 were analyzed as a split-plot, crossover design with a $2 \times 3$ factorial arrangement of treatments using the mixed procedure of SAS (1990). Steer was the experimental unit with the model including dietary treatment, level of intake variation, and the dietary treatment $\times$ level of intake variation interaction. Steer, period, and the steer $x$ period interaction were random effects. No dietary treatment $\times$ intake variation interaction was detected ( $P>.10)$; therefore, only means for level of intake variation are presented. Least squares means were separated using least significant difference method when a significant $(P<.10)$ F-test was detected.

\section{Finishing Trials}

Two finishing trials were conducted to evaluate the effect of imposed feed intake variation on performance of finishing steers. In Finishing Trial 1, crossbred yearling steers ( $n=75$; average initial weight $=282 \pm$ $7.1 \mathrm{~kg}$ ) were used in a randomized complete block design. Steers were blocked by weight and allotted randomly within block to one of two treatments (four replications per treatment). Treatments consisted of two levels of imposed feed intake variation: $A L$ or an HV of $1.8 \mathrm{~kg} / \mathrm{d}$. Steers were fed a $93.3 \%$ concentrate diet once daily that contained (DM basis) $51.7 \%$ dryrolled corn, 35\% high moisture corn, 5\% alfalfa, 3.3 corn silage, and $5 \%$ dry supplement. Diets were formulated to contain a minimum of $12.5 \% \mathrm{CP}, .7 \%$ calcium, .3\% phosphorus, and $.6 \%$ potassium, with $27.5 \mathrm{mg} / \mathrm{kg}$ monensin (Elanco Animal Health) and $11.0 \mathrm{mg} / \mathrm{kg}$ tylosin (Elanco Animal Health).

In Finishing Trial 2, crossbred yearling steers ( $\mathrm{n}=$ 94; average initial weight $=298 \pm 3.6 \mathrm{~kg}$ ) were used in a completely randomized design with a $2 \times 2$ factorial arrangement of treatments. Steers were allotted randomly to 1 of 12 pens. Pens were then allotted randomly to one of two dietary treatments and to one of two levels of intake variation. Dietary treatments consisted of a control diet balanced for $13.5 \% \mathrm{CP}$ and $.35 \% \mathrm{P}$, and a diet balanced to match but not exceed the MP and $P$ requirements using the NRC model (1996). The control diet contained (DM basis) $81.3 \%$ dry-rolled corn, $7.5 \%$ alfalfa, $6.2 \%$ molasses-urea liquid supplement, and $5 \%$ dry supplement. The balanced diet contained (DM basis) $64.5 \%$ highmoisture corn, $20.1 \%$ corn bran, $7.5 \%$ alfalfa, $2.9 \%$ tallow, and $5 \%$ dry supplement. Both diets contained $27.5 \mathrm{mg} / \mathrm{kg}$ monensin (Elanco Animal Health) and $11.0 \mathrm{mg} / \mathrm{kg}$ tylosin (Elanco Animal Health). Levels of intake variation consisted of $\mathrm{AL}$ or an $\mathrm{HV}$ of $1.8 \mathrm{~kg} / \mathrm{d}$.

In both finishing trials, steers on the HV treatment were given ad libitum access to feed from $d 1$ through 34 . Then, based on each pen's average DMI from d 28 through 34 , each pen was subjected to imposed feed intake variation of $1.8 \mathrm{~kg} / \mathrm{d}$ from d 35 through d 140 on feed for Finishing Trial 1, and through d 147 on feed for Finishing Trial 2. This was accomplished by first decreasing the feed offered by $.9 \mathrm{~kg}$ from each pen's average DMI on $d 36$. Then, on $d 37$, the amount of feed offered was increased by $1.8 \mathrm{~kg}$, followed by a $1.8 \mathrm{~kg}$ decrease on d 38, then a $1.8 \mathrm{~kg}$ increase on d 39, and so forth. In order to maintain the average amount of feed offered at ad libitum levels, a $.5 \mathrm{~kg} / \mathrm{d}$ adjustment factor was used. If feed remained in the bunk on the morning following a day when a low level of feed was offered $(-1.8 \mathrm{~kg})$, the feed offered was only increased by $1.3 \mathrm{~kg}$ on that day, followed by a $1.8 \mathrm{~kg}$ decrease the next day, in effect decreasing the average feed offered to the steers by $.5 \mathrm{~kg}$. Conversely, if a bunk was empty the morning following a day when a high level of feed was offered $(+1.8 \mathrm{~kg})$, the feed offered was only decreased by $1.3 \mathrm{~kg}$ on that day, followed by a $1.8 \mathrm{~kg}$ increase the next day, in effect increasing the average feed offered to the steers by .5 $\mathrm{kg}$. With this system, feed intake variation could be imposed on individual pens based on their own ad libitum intake.

In both feedlot trials, steers were weighed initially on two consecutive days after being limit-fed a 50\% grass hay:50\% wet corn gluten feed diet at 2\% (DM basis) of BW for $5 \mathrm{~d}$ to minimize fill differences. Daily gain was calculated based on initial weight taken at the start of the adaptation period and final weight. Final weight was based on hot carcass weight, taken at slaughter, adjusted to a common $62 \%$ dressing percentage. 
Data from Feedlot Trial 1 were analyzed as a randomized complete block design using the GLM procedure of SAS (1985). Pen was the experimental unit, and the model included block and treatment. Least squares means were separated using least significant difference method when a significant ( $\mathrm{P}<$ .10) F-test was detected.

Data from Feedlot Trial 2 were analyzed as a completely randomized design with a $2 \times 2$ factorial arrangement of treatments using the GLM procedure of SAS (1985). Pen was the experimental unit and the model included diet, intake variation, and the diet $x$ intake variation interaction. Least squares means were separated using least significant difference method when a significant $(\mathrm{P}<.10) \mathrm{F}$-test was detected.

\section{Results and Discussion}

\section{Metabolism Trials}

In Metabolism Trial 1, no significant differences in DMI, rate of intake, average ruminal $\mathrm{pH}$, or area of ruminal $\mathrm{pH}$ below $5.6(\mathrm{P}>.10)$ were noted between treatments of $C$ or $L V$ of $.7 \mathrm{~kg} / \mathrm{d}$ (Table 1 ). In Metabolism Trial 2, no significant differences in DMI, rate of intake, and average ruminal $\mathrm{pH}(\mathrm{P}>.10)$ were noted between treatments of $C$ and $H V$ of $1.4 \mathrm{~kg} / \mathrm{d}$ (Table 1). However, area of ruminal pH below 5.6 was increased $(\mathrm{P}<.05)$ by 75 units (magnitude of $\mathrm{pH}$ bel ow 5.6 by $\mathrm{min}$ ) in the HV treatment compared with C.

Results of Metabolism Trial 1 indicate that within a limit-feeding system, daily intake variation of .7 kg/d did not significantly alter measures of intake or acidosis; however, rate of intake and area of ruminal $\mathrm{pH}$ below 5.6 numerically increased with intake variation. Within a limit-feeding system, intake variation of $1.4 \mathrm{~kg} / \mathrm{d}$ (Metabolism Trial 2) increased subacute acidosis in steers as measured by the area of ruminal $\mathrm{pH}$ below 5.6. In addition, rate of intake, although not significant, numerically increased with the HV treatment. Even though Metabolism Trials 1 and 2 were separate trials, they were consecutive and involved the same steers. Therefore, these two trials indicate that within a limit-feeding system, there may be a linear response of increased acidosis with increasing levels of imposed feed intake variation. It is important to note that average ruminal $\mathrm{pH}$ would not have provided the same conclusions because it was not significantly affected in either trial. Area of ruminal $\mathrm{pH}$ below 5.6 should provide a more accurate measure of acidosis, and therefore, conclusions were based on this trait.

The results of Metabolism Trials 1 and 2 agree with those of Galyean et al. (1992). They found that within a limit-feeding system, $10 \%$ daily feed intake variation ( $\pm 20 \%$ over a 2 -d period) decreased daily gain by
Table 1. Effect of imposed intake variation on intake and subacute acidosis of limit-fed steers in metabolism Trials 1 and 2

\begin{tabular}{|c|c|c|c|}
\hline \multirow[b]{2}{*}{ Item } & \multicolumn{2}{|c|}{ Treatment } & \multirow[b]{2}{*}{ SEM } \\
\hline & Constant $^{a}$ & $\begin{array}{l}\text { Intake } \\
\text { variation }\end{array}$ & \\
\hline \multicolumn{4}{|l|}{ Metabolism Trial 1} \\
\hline Daily DMI, kg & 8.1 & 7.9 & .5 \\
\hline Rate of intake, \%/h & 53.4 & 67.0 & 31.2 \\
\hline Average ruminal $\mathrm{pH}$ & 5.95 & 5.85 & .26 \\
\hline $\begin{array}{l}\text { Area of ruminal pH } \\
\text { below } 5.6^{c}\end{array}$ & 97.7 & 151.7 & 63.7 \\
\hline \multicolumn{4}{|l|}{ Metabolism Trial 2} \\
\hline Daily DMI, kg & 8.2 & 8.2 & .4 \\
\hline Rate of intake, $\% / \mathrm{h}$ & 46.0 & 70.7 & 22.6 \\
\hline Average ruminal $\mathrm{pH}$ & 5.84 & 5.82 & .23 \\
\hline $\begin{array}{l}\text { Area of ruminal pH } \\
\text { below } 5.6^{\text {cd }}\end{array}$ & 106.2 & 180.9 & 83.7 \\
\hline \multicolumn{4}{|c|}{$\begin{array}{l}\text { aConstant amount of feed offered per day at approximately } 80 \% \\
\text { ad libitum. } \\
\text { bDaily intake variation of } .7 \mathrm{~kg} / \mathrm{d} \text { in Metabolism Trial } 1 \text { and } 1.4 \\
\mathrm{~kg} / \mathrm{d} \text { in Metabolism Trial } 2 \text {, based on the level of feed offered in the } \\
\text { constant treatment. } \\
\text { cArea = magnitude of ruminal pH below } 5.6 \text { by minute. } \\
\text { dMeans differ }(\mathrm{P}<.05) \text {. }\end{array}$} \\
\hline
\end{tabular}

6.5\%. The average DMI in their trial was $7.8 \mathrm{~kg} / \mathrm{d}$. Therefore, $10 \%$ daily intake variation was approximately $.8 \mathrm{~kg} / \mathrm{d}$ (or $1.6 \mathrm{~kg}$ over $2 \mathrm{~d}$ ), which would fall between our LV and HV levels of intake variation. The increased acidosis measured in Metabolism Trial 2 might explain the decrease in performance noted by Galyean et al. (1992) with limit-fed steers. Even though rate of intake was not significantly altered by treatment in these trials, it seems likely that the numerical trend for increased rate of intake with increasing levels of intake variation may explain the increase in acidosis measured in Metabolism Trial 2.

In Metabolism Trial 3, with the treatments of $A L$, LV of .7 kg/d, and HV of $1.4 \mathrm{~kg} / \mathrm{d}$, no differences in $\mathrm{DMI}$, rate of intake, average ruminal $\mathrm{pH}$, or area of ruminal pH below 5.6 were noted (Table 2). However, area of ruminal pH below 5.6 decreased numerically ( $\mathrm{P}=.28, \mathrm{AL}$ versus $\mathrm{HV}$ ) as level of intake variation increased. Therefore, the same steers fed under the same general conditions did not respond similarly to imposed intake variation when fed at ad libitum levels of intake compared with being limit-fed. The results from Metabolism Trial 3 must be used with caution because period and treatment were confounded.

In Metabolism Trial 4, with the treatments of $A L$, LV of $.9 \mathrm{~kg} / \mathrm{d}$, and $\mathrm{HV}$ of $1.8 \mathrm{~kg} / \mathrm{d}$, DMI was not affected by level of intake variation and averaged 12.8 $\mathrm{kg} / \mathrm{d}$ (Table 2). Rate of intake tended $(P=.13)$ to increase for $L V$ and $H V$ compared with $A L$, but the $L V$ and $\mathrm{HV}$ treatments were similar. Average ruminal $\mathrm{pH}$ increased $(P<.01)$ across levels of imposed intake variation of $A L(0), .9$, and $1.8 \mathrm{~kg} / \mathrm{d}$. In addition, area of ruminal pH below 5.6 decreased $(P<.05)$ as level 
Table 2. Effect of imposed intake variation on intake and subacute acidosis of steers fed at ad libitum levels in metabolism Trials 2 and 3

\begin{tabular}{|c|c|c|c|c|}
\hline \multirow[b]{2}{*}{ Item } & \multicolumn{3}{|c|}{ Treatment } & \multirow[b]{2}{*}{ SEM } \\
\hline & Ad libitum ${ }^{a}$ & $\begin{array}{l}\text { Low } \\
\text { variation }\end{array}$ & $\begin{array}{l}\text { High } \\
\text { variationc }\end{array}$ & \\
\hline \multicolumn{5}{|l|}{ Metabolism Trial 3} \\
\hline Daily DMI, kg & 9.9 & 9.8 & 10.0 & .9 \\
\hline Rate of intake, \%/h & 22.2 & 25.6 & 24.5 & 4.1 \\
\hline Average ruminal $\mathrm{pH}$ & 5.63 & 5.63 & 5.67 & .17 \\
\hline Area of ruminal $\mathrm{pH}$ below $5.6^{\mathrm{d}}$ & 227.4 & 187.0 & 180.0 & 87.0 \\
\hline \multicolumn{5}{|l|}{ Metabolism Trial 4} \\
\hline Daily DMI, kg & 13.1 & 12.7 & 12.7 & .4 \\
\hline Rate of intake, \%/h & 31.4 & 37.9 & 35.9 & 6.3 \\
\hline Number of meals per $d$ & 9.5 & 8.8 & 8.8 & .6 \\
\hline Time spent eating per $d$, min & 331 & 291 & 306 & 15 \\
\hline Average meal size, $\mathrm{kg}$ & 1.5 & 1.7 & 1.6 & .2 \\
\hline Average ruminal $\mathrm{pH}$ & $5.55^{\mathrm{e}}$ & $5.68^{f}$ & $5.76^{f}$ & .07 \\
\hline Area of ruminal $\mathrm{pH}$ below $5.6^{\mathrm{d}}$ & $215.8^{e}$ & $154.1^{\mathrm{ef}}$ & $94.7^{f}$ & 52.6 \\
\hline
\end{tabular}

of intake variation increased. Both of these measurements indicate a reduction in acidosis as level of intake variation increased.

In Metabolism Trial 4, the number of meals per day, total time spent eating per day, and the average meal size were calculated (Table 2). The number of meals per day was not affected by intake variation, and averaged nine meals per day. The total time spent eating per day decreased $(P<.05)$ from $A L$ to $L V$. The $\mathrm{HV}$ treatment also tended $(\mathrm{P}=.12)$ to reduce total time spent eating per day compared with $A L$, but was similar to LV. The average meal size was not affected by level of intake variation and averaged $1.6 \mathrm{~kg} / \mathrm{meal}$.

To explain the responses of average ruminal $\mathrm{pH}$ and area of ruminal pH below 5.6 in Metabolism Trial 4, periods of imposed intake variation were analyzed within days of low and high amount of feed offered (Table 3). Low variation was divided into the days of $-.9 \mathrm{~kg}(\mathbf{L V L})$ and days of $+.9 \mathrm{~kg}$ ( LVH) of feed offered from a steer's base ad libitum intake. Likewise, $\mathrm{HV}$ was divided into days of $-1.8 \mathrm{~kg}$ ( HVL) and days of $+1.8 \mathrm{~kg}(\mathbf{H V H})$. The average ruminal $\mathrm{pH}$ and area of ruminal pH below 5.6 were not different between LVL and LVH, nor between HVL and HVH. Not only did these measures indicate that acidosis decreased as level of intake variation was increased, but they were not different between the low and high days of feed offered within level of intake variation.

The results of Metabolism Trials 3 and 4 suggest that steers fed at ad libitum levels of intake do not

Table 3. Effect of daily amount of feed offered during periods of imposed intake variation on intake and subacute acidosis of steers fed at ad libitum levels in Metabolism Trial 4

\begin{tabular}{|c|c|c|c|c|c|c|}
\hline \multirow[b]{2}{*}{ Item } & \multicolumn{5}{|c|}{ Treatment } & \multirow[b]{2}{*}{ SEM } \\
\hline & $A L^{a}$ & $\operatorname{LVL}^{\mathrm{b}}$ & $\mathrm{LVH}^{\mathrm{C}}$ & $\mathrm{HVL}^{\mathrm{d}}$ & $\mathrm{HVH}^{\mathrm{e}}$ & \\
\hline Daily DMI, kg & $13.1^{\mathrm{fg}}$ & $12.3^{\mathrm{h}}$ & $13.1^{\mathrm{g}}$ & $11.8^{\mathrm{i}}$ & $13.6^{f}$ & .4 \\
\hline Number of meals per $d$ & $9.5^{f}$ & $8.5^{\mathrm{g}}$ & $8.5^{\mathrm{g}}$ & $7.9^{9}$ & $9.3^{9}$ & .8 \\
\hline Average meal size, kg & 1.5 & 1.6 & 1.7 & 1.7 & 1.6 & .2 \\
\hline Average ruminal $\mathrm{pH}$ & $5.55^{f}$ & $5.71^{\text {gh }}$ & $5.64^{f g}$ & $5.78^{h}$ & $5.75^{\mathrm{h}}$ & .08 \\
\hline Area of ruminal pH below 5.6 & $215.8^{f}$ & $139.2^{\mathrm{gh}}$ & $169.0^{\mathrm{fg}}$ & $96.6^{\mathrm{h}}$ & $92.8^{\mathrm{h}}$ & 52.7 \\
\hline
\end{tabular}

${ }^{\text {aAd }}$ libitum intake with no imposed intake variation.

${ }^{b}$ Days of low amount $(-.9 \mathrm{~kg})$ of feed offered during periods of low intake variation (LV).

'Days of high amount $(+.9 \mathrm{~kg})$ of feed offered during periods of low intake variation (LV).

dDays of low amount $(-1.8 \mathrm{~kg})$ of feed offered during periods of high intake variation (HV).

eDays of high amount $(+1.8 \mathrm{~kg})$ of feed offered during periods high intake variation $(\mathrm{HV})$.

$f, g, h, r$ Within a row, means lacking a common superscript letter differ $(P<.10)$.

jArea $=$ magnitude of ruminal pH below 5.6 by minute. 
experience increased acidosis with imposed intake variation of up to $1.8 \mathrm{~kg} / \mathrm{d}$. In fact, the results support a reduced incidence of acidosis with increased level of intake variation. However, this is difficult to explain. It might be plausible that when the steers were subjected to intake variation, the days of reduced feed offered actually allowed the steers to build buffer capacity or base-excess, so that, even upon overconsumption the following day, acidosis was not induced. However, this is speculation. Further work with rumen and blood metabolites would be needed to substantiate such a mechanism. One thing is clear, the steers fed at ad libitum levels, under the conditions of these trials, did not experience more acidosis with increased intake variation.

\section{Finishing Trials}

Dry matter amounts offered to pens of cattle in Finishing Trials 1 and 2 are shown in Figures 1 and 2 , respectively. In these figures, DM offered is averaged by level of intake variation for d 35 through d 140 (Trial 1) and d 147 (Trial 2). Although these figures depict feed offered, actual DMI should be very similar because the daily amount offered was adjusted so that feed would not accumulate in the bunk. The overall pattern of DMI was very similar between levels of intake variation for both trials. However, there was more day-to-day intake variation in the pens on the $\mathrm{HV}$ treatments, as would be expected because of the imposed intake variation of $1.8 \mathrm{~kg} / \mathrm{d}$. In both finishing trials, average absolute daily change in amount of DM offered was $.3 \mathrm{~kg} / \mathrm{d}$ for $A L$ and $1.6 \mathrm{~kg} / \mathrm{d}$ for HV. It is important to note that DMI was not constant for pens on the AL treatment. For these pens, daily amount of feed offered was adjusted to avoid both feed accumulation and an empty bunk. It was a goal to always have feed available to cattle on the $A L$ treatment.

In Finishing Trial 1, overall DMI was higher ( $\mathrm{P}<$ .05) in the HV treatment than in the AL treatment (Table 4). However, no differences in daily gain or gain/feed $(P>.10)$ were noted due to intake variation. In Finishing Trial 2, no differences in DMI, daily gain,

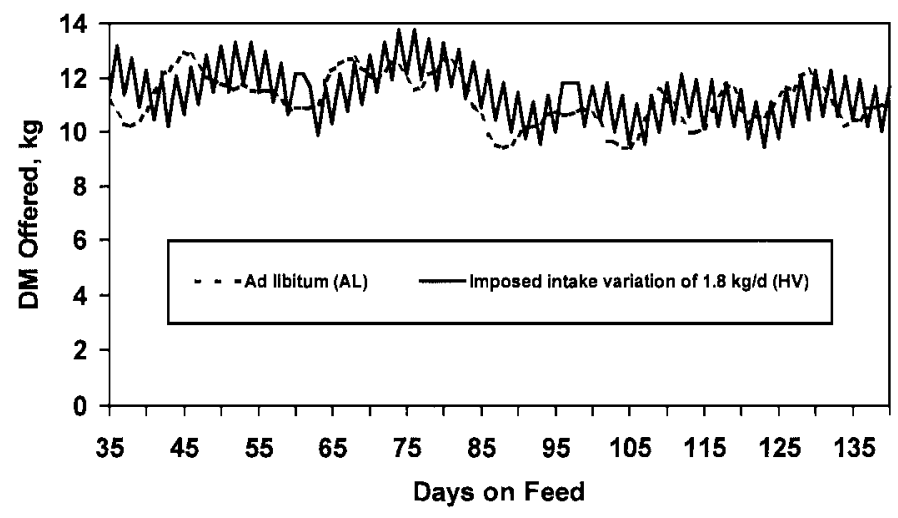

Figure 1. Dry matter offered by treatment in Finishing Trial 1.

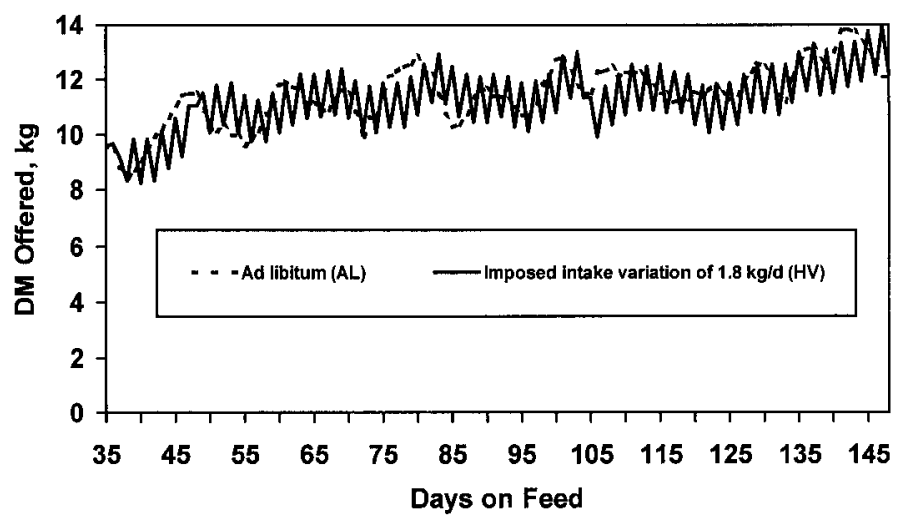

Figure 2. Dry matter offered by treatment in Finishing Trial 2.

or gain/feed were noted due to intake variation (Table $4)$. No dietary treatment $x$ intake variation interaction was observed $(P>.10)$; therefore, only means for level of intake variation are presented.

The results of Finishing Trials 1 and 2 indicate that imposed intake variation of $1.8 \mathrm{~kg} / \mathrm{d}$ did not decrease performance of finishing steers fed at ad libitum levels of intake compared with steers fed ad libitum. These performance results complement the results of Metabolism Trials 3 and 4, but do not agree with those of Galyean et al. (1992). However, the difference may be due to the level of feed offered. In the trial conducted by Galyean et al. (1992), steers were programmed or limit-fed to gain $1.3 \mathrm{~kg} / \mathrm{d}$. As mentioned previously, they found that daily intake variation of $10 \%$ per day decreased daily gain by $6.5 \%$ compared with constant intake per day. However, the authors also noted that treatment differences narrowed as the steers increased in body weight and presumably approached ad libitum because they were fed as a percentage of body weight. Therefore, the results of Galyean et al. (1992) might agree with the conclusion that imposed intake variation does not

Table 4. Effect of imposed intake variation on performance of steers fed at ad libitum levels

\begin{tabular}{|c|c|c|c|}
\hline \multirow[b]{2}{*}{ Item } & \multicolumn{2}{|c|}{ Treatment } & \multirow[b]{2}{*}{ SEM } \\
\hline & $\begin{array}{c}\text { Ad } \\
\text { libitum }^{a}\end{array}$ & $\begin{array}{c}\text { Intake } \\
\text { variation }\end{array}$ & \\
\hline \multicolumn{4}{|l|}{ Finishing Trial 1} \\
\hline Daily DMI, kg & 10.8 & 11.0 & .04 \\
\hline Daily gain, kg & 1.71 & 1.75 & .03 \\
\hline Gain/DMI & .159 & .159 & .003 \\
\hline \multicolumn{4}{|l|}{ Finishing Trial 2} \\
\hline Daily DMI, kg & 11.2 & 11.0 & .1 \\
\hline Daily gain, kg & 1.85 & 1.80 & .02 \\
\hline Gain/DMI & .165 & .163 & .003 \\
\hline
\end{tabular}

${ }^{a}$ Ad libitum feed offered with no imposed intake variation. bDaily intake variation of $1.8 \mathrm{~kg} / \mathrm{d}$ from d 35 through slaughter. cMeans differ $(P<.05)$. 
seem to have much of an effect on performance of steers fed at ad libitum levels of intake.

Zinn (1994) limit-fed steers to gain $1.1 \mathrm{~kg} / \mathrm{d}$ with or without $20 \%$ daily intake variation. No differences in performance were noted due to intake variation. SotoNavarro et al. (1997) limit-fed steers to gain $1.25 \mathrm{~kg} / \mathrm{d}$ and found that $10 \%$ feed intake variation numerically reduced ADG and gain/feed of steers from d 0 to 56. However, from d 57 to 84, ADG and gain/feed were numerically higher for steers with $10 \%$ intake variation. Therefore, $10 \%$ intake variation did not affect performance of limit-fed steers over an 84-d period. These authors concluded that the steers may become adapted to the $10 \%$ intake variation, which may have also occurred in Feedlot Trials 1 and 2. In a different trial, Soto-Navarro et al. (1998) limit fed steers to either gain .9 or $1.25 \mathrm{~kg} / \mathrm{d}$ with or without $10 \%$ feed intake variation. They found that $10 \%$ intake variation did not affect DMI or ADG at either prescribed rate of gain.

Bierman and Pritchard (1996) evaluated the effects of intake variation on performance of steers fed at near ad libitum levels. However, instead of imposing feed intake variation, they measured the results from minimizing the variations in feed deliveries. They found that controlling variation caused an improvement in gain/feed without affecting ADG. F eedl ot Trials 1 and 2 applied variation to cattle fed at ad libitum levels; whereas, Bierman and Pritchard (1996) tried to reduce variation associated with ad libitum feeding. Pritchard (1998) compared these results and concluded that applying systemic fluctuations in feed deliveries to an al ready variable line is of little or no consequence.

These conclusions do not mean that feed intake variation and acidosis are not related. Stock et al. (1995) calculated daily intake variance (AIV) using the individual feeding data from Burrin et al. (1988), Britton et al. (1991), Bauer et al. (1995), Huffman et al. (1993), Klopfenstein et al. (1995), and Krehbiel et al. (1995a,b). Intake variance was calculated for each trial using intake residuals and was correlated to gain/feed. Across trials, AIV was correlated negatively ( $r=-.28)$ with gain/feed.

From these studies, it can be concluded that there is a weak negative relationship between intake variation and performance. However, the cause and effect was not established. The results from Metabolism Trials 3 and 4 and Finishing Trials 1 and 2 would suggest that intake variation does not cause acidosis or reduced gain efficiency. Therefore, it seems likely that subacute acidosis is the cause of intake variation.

\section{Implications}

The results of these trials indicate that intake variation by cattle fed high-concentrate diets at ad libitum levels of intake does not increase acidosis or reduce feedlot performance. However, there is some indication that intake variation by cattle in a limitfeeding system may increase the incidence of acidosis.

\section{Literature Cited}

Bauer, M. L., D. W. Herold, R. A. Britton, R. A. Stock, T. J. Klopfenstein, and D. A. Yates. 1995. Efficacy of Iaidlomycin propionate to reduce ruminal acidosis in cattle. J. Anim. Sci. 73:3445-3454.

Bierman, S. J ., and R. H. Pritchard. 1996. Effect of feed delivery management on yearling steer performance. S.D. Agric. Exp. Stn. Beef Report CATTLE 96-5:17-22.

Britton, R., R. Stock, M. Sindt, B. Oliveros, and C. Parrott. 1991. A new feed additive and technique to evaluate acidosis in cattle. Nebr. Beef Cattle Rep. MP 56:55-58.

Burrin, D. G., R. A. Stock, and R. A. Britton. 1988. Monensin level during grain adaptation and finishing performance in cattle. J . Anim. Sci. 66:513-521.

Fulton, W. R., T. J . Klopfenstein, and R. A. Britton. 1979. Adaptation to high concentrate diets by beef cattle. I. Adaptation to corn and wheat diets. J. Anim. Sci. 49:775-784.

Galyean, M. L., K. J. Malcolm-Callis, D. R. Garcia, and G. D. Pulsipher. 1992. Effects of varying the pattern of feed consumption on performance by programmed-fed steers. N.M. Agric. Exp. Stn. PR 78.

Huffman, R., R. Stock, and R. Britton. 1993. Fat addition on subacute ruminal acidosis. Nebr. Beef Cattle Rep. MP 59A:58-60.

Klopfenstein, T., R. Huffman, and R. Stock. 1995. Effect of Lactobacillus acidophilus on subacute acidosis and cattle performance. Nebr. Beef Cattle Rep. MP 62-A:37-38.

Krehbiel, C. R., R. A. Stock, D. W. Herold, D. H. Shain, G. A. Ham, and J. E. Carulla. 1995a. Feeding wet corn gluten feed to reduce subacute acidosis in cattle. J . Anim. Sci. 73:2931-2939.

Krehbiel, C. R., R. A. Stock. D. H. Shain, C. J . Richards, G. A. Ham, R. A. McCoy, T. J. Klopfenstein, R. A. Britton, and R. P. Huffman. 1995b. Effect of level and type of fat on subacute acidosis in cattle fed dry-rolled corn finishing diets. J. Anim. Sci. 73:2438-2446.

NRC. 1996. Nutrient Requirements of Beef Cattle (6th Ed.). National Academy Press, Washington, DC.

Pritchard, R. H. 1998. Bunk management-Observations from research. Plains Nutr. Council Spring Conf., San Antonio, TX. p 68.

SAS. 1985. SAS User's Guide: Statistics (Version 5 Ed.). SAS Inst. Inc., Cary, NC.

SAS. 1990. SAS User's Guide: Statistics (Version 6 Ed.). SAS Inst. Inc., Cary, NC.

Soto-Navarro, S. A., G. C. Duff, M. L. Galyean, K. J . Malcom-Callis, and C. R. Krehbiel. 1997. Influence of feed intake fluctuation and frequency of feeding on performance in limit-fed steers. $J$. Anim. Sci. 75 (Suppl. 1):119 (Abstr.).

Soto-Navarro, S. A., G. C. Duff, K. J. Malcom-Callis, and C. R. Krehbiel. 1998. Influence of rate of gain and feed intake fluctuation in limit-fed steers. Plains Nutr. Council Spring Conf., San Antonio, TX. p 100.

Stock, R., T. Klopfenstein, and D. Shain. 1995. Feed intake variation. In: Symposium: Intake by Feedlot Cattle. Okla. Agric. Exp. Stn. P-942:56-59.

Stock, R. A., M. H. Sindt, R. M. Cleale, IV, and R. A. Britton. 1991. High-moisture corn utilization in finishing cattle. J . Anim. Sci. 69:1645-1656.

Zinn, R. A. 1994. Influence of fluctuating feed intake on feedlot cattle growth-performance and digestive function. Southwest Nutr. Manage. Conf., Phoenix, AZ. p 77. 